\title{
A PRISÃO PREVENTIVA E O PRINCÍPIO DA PROPORCIONALIDADE: PROPOSTA DE MUDANÇAS LEGISLATIVAS*
}

THE PREVENTIVE CUSTODY AND THE PRINCIPLE OF PROPORTIONALITY: PROPOSITION OF

LEGISLATIVE AMENDMENTS

Gustavo Henrique Righi Ivahy Badaró ${ }^{* *}$

\begin{abstract}
Resumo:
O presente texto analisa a necessidade de que haja uma relação de proporcionalidade entre a prisão preventiva, como modalidade de prisão cautelar, e a pena que provavelmente será aplicada ao final do processo, em caso de condenação. A proporcionalidade com a pena a ser futuramente aplicada é um requisito, ainda que implícito, para a decretação de qualquer prisão cautelar. De outro lado, sempre que no curso do processo, o juiz verificar que, diante da provável pena a ser aplicada, o acusado não será submetido à pena privativa de liberdade, deverá revogar a prisão. Diante disso, propõe-se uma alteração do Código de Processo Penal, explicitando que a proporcionalidade é um requisito para a decretação das prisões preventiva e, por outro lado, a desproporção com a pena provável autoriza a revogação de tal medida cautelar.
\end{abstract}

Palavras-chaves: Medida cautelar. Prisão preventiva: requisitos, proporcionalidade, revogação. Proposta de alteração legislativa.

\begin{abstract}
:
This paper examines the need for a relationship of proportionality between preventive custody, as a kind of preventative measure imprisonment, and the penalty which will probably be implemented at the end of the process, in case of conviction. The proportionality with the penalty to be applied in future is a requirement, even implicit, to any preventive custody. In addition, if, in the course of the proceeding, the judge thinks that the probable penalty to be applied will not be the punishment by confinement, he shall revoke the preventive custody. Given this, it is proposed an amendment to the Criminal Procedure Code, to make it clear that the proportionality is a requirement for preventive custody. And, on the other hand, the disproportion with the probable penalty to be applied authorizes the repeal of that preventive measure.
\end{abstract}

Keywords: Preventive Measure. Preventive custody: requirements, proportionality, revocation. Amendment to the Criminal Procedure Code.

\footnotetext{
Substancialmente, o presente estudo tem por base a pesquisa realizada para a elaboração do artigo "A Prisão preventiva e o princípio da proporcionalidade", publicado na obra Estudos Criminais em Homenagem a Weber Martins Batista. LIMA, Marcellus Polastri; RIBEIRO, Bruno de Morais (Org.). Rio de Janeiro: Lumen Juris, 2008. A diferença em relação àquele estudo, encontra-se numa pequena alteração no item 1 , bem como na inclusão dos itens 8 e 9, em que diante das premissas lançadas naquele estudo, analisa-se o projeto de reforma do Código de Processo Penal, que tem por objeto da prisão cautelar, bem como se formula uma proposta de alteração legislativa para, ao menos nesse aspecto, buscar-se adequar o processo penal brasileiro à Constituição de 1988 e torná-lo mais justo, para esse século XXI.

** Professor Doutor de Direito Processual Penal da Faculdade de Direito da Universidade de São Paulo e da Universidade de Taubaté. Advogado Criminalista.
} 
1. Introdução: a evolução legislativa da prisão cautelar

Desde que o Código de Processo Penal entrou em vigor, profundas foram as mudanças legislativas tendo por objeto a prisão cautelar.

Em seu sistema originário, o Código de Processo Penal trazia uma modalidade de prisão preventiva obrigatória, para os casos de acusação tendo por objeto crimes cuja pena máxima fosse igual ou superior a 10 anos. ${ }^{1}$

Além disso, no caso de prisão em flagrante, o acusado somente poderia livrar-se solto nos casos de crimes cuja pena privativa de liberdade não excedesse 3 meses, ou obter a liberdade provisória, mediante fiança, para os crimes cuja pena máxima fosse de até 2 anos, ${ }^{2}$ ou, finalmente, ter concedida a liberdade provisória sem fiança, no caso em que o fato tivesse sido praticado em hipótese de excludente de ilicitude. ${ }^{3}$

Por outro lado, se tivesse respondido o processo e liberdade, a sentença condenatória recorrível, em regra, implicaria a necessidade de seu recolhimento à prisão que, aliás, era um dos efeitos da sentença penal condenatória. Somente poderia apelar em liberdade, nos casos em que pudesse livrar-se solto ou prestar fiança que, na época, como já ressaltado, somente era cabível para os crimes cuja pena máxima fosse de até 2 anos.

Algumas décadas depois, iniciam-se as mudanças.

A primeira delas se deu com a Lei n. 5.349, de 3 de novembro de 1967, que eliminou a prisão preventiva obrigatória, que nada tinha de cautelar, sendo um simples corolário automático da imputação, independendo de qualquer verificação do periculum libertatis.

Na seqüência, merece ser lembrada a Lei n. 5.941, de 22 de novembro de 1973, que alterou a redação do art. 594, para permitir que também pudesse apelar em liberdade, o acusado que fosse primário e tivesse bons antecedentes. ${ }^{4}$

\footnotetext{
A redação originária do citado artigo era: "Art. 312. A prisão preventiva será decretada nos crimes a que for cominada pena de reclusão por tempo, no máximo, igual ou superior a dez anos". Comentando tal dispositivo, (MARQUES, José Frederico. A prisão preventiva compulsória. In: Estudos de direito processual penal. Rio de Janeiro: Forense, 1960. p. 227) após afirmar que o CPP de 1941 ficou vincado "com as marcas indeléveis da era totalitária em que foi promulgado", acrescentava: "a prisão preventiva compulsória é um dos exemplos desse autoritarismo processual que devemos à política direitista do Estado Novo trasladada do processo penal italiano da era de Mussolini, essa medida de coação é de profunda iniqüidade e pode dar margem à prática de irreparáveis injustiças".

2 Em sua redação originária, o art. 323, inc. II, do CPP dispunha; "Não será concedida fiança: I - nos crimes punidos com pena de reclusão, salvo ao réu maior de setenta anos ou menor de vinte e um, no caso de não ser superior a dois anos o máximo de pena cominada".

3 Isso porque, em sua redação originária, não havia o parágrafo único do art. 310, que somente foi acrescentado pela Lei n. 6.416, de 24 de maio de 1977.

4 A redação originária do art. 594 era: "O réu não poderá apelar sem recolher-se à prisão, ou prestar fiança, salvo se condenado por crime de que se livre solto". A nova redação ampliou as exceções à regra de que o acusado teria que se recolher à prisão para apelar. A nova redação do art. 594 passou a ser: "O réu não poderá apelar sem recolher-se à prisão, ou prestar fiança, salvo se for primário e de bons antecedentes, assim reconhecido
} 
Depois, a Lei n. 6.416, de 24 de maio de 1977, que, entre outras alterações, introduziu o parágrafo único do art. 310 do Código de Processo Penal, representou uma profunda modificação, dando à prisão em flagrante natureza verdadeiramente cautelar. ${ }^{5} \mathrm{Ou}$ seja, sua manutenção somente ocorreria nos casos em que se mostrasse necessária, diante da presença de uma das hipóteses que autorizavam a prisão preventiva.

Sem dúvida, o ponto máximo dessa evolução ocorre com a Constituição de 1988 que, no que importa diretamente ao presente tema, passou a prever, expressamente, o princípio da presunção de inocência (art. $5^{\circ}$, inc. LVII) ou "estado de inocência", como preferem alguns.

Além disso, no plano da legislação ordinária foram muitas as "reformas pontuais" ou, nas palavras de Ferrajoli, uma "metástase legislativa": 6 uma "nova" Parte Geral do Código Penal, a chamada Lei dos Crimes Hediondos, a Lei dos Juizados Especiais Criminais, a Lei das "Penas Alternativas", a Lei dos Juizados Especiais Federais e, mais recentemente, a Lei n. 11.340, de 07 de agosto de 2006, conhecida como Lei da Violência Doméstica, e a Lei n. 11.313, de 28.06.2006, que alterou a definição de infração de menor potencial ofensivo. Desnecessário destacar a total quebra de harmonia e a perda de coerência sistêmica que tais alterações provocaram.

De todas as incoerências, apenas uma será analisada no presente artigo: a desproporção de se decretar a prisão preventiva nos casos em que, segundo a pena a ser provavelmente aplicada, o acusado não será punido com pena privativa de liberdade. De forma mais simples: se não se vai prender ao final, não se pode prender durante o processo!

Para melhor justificar a proposição acima, necessário se faz analisar, ainda que sucintamente, a tutela cautelar e a finalidade da prisão preventiva.

2. Tutela cautelar e tutela antecipada

Não se fazem mais necessárias discussões acaloradas sobre a autonomia da tutela cautelar ${ }^{7}$ e, mais do que isso, sobre a necessidade de que o sistema processual

na sentença condenatória, ou condenado por crime de que se livre solto". Mudança semelhante ocorreu com a pronúncia, no procedimento dos crimes doloso contra a vida, tendo em vista a alteração da redação do art. $408, \S 2^{\circ}$, que passou a permitir a interposição de recurso em liberdade, "§ $2^{\circ}$. Se o réu for primário e de bons antecedentes, poderá o juiz deixar de decretar-lhe a prisão ou revogá-la, caso já se encontre preso".

5 Em magnífica obra sobre Liberdade Provisória, assinalou (BATISTA, Weber Martins. Liberdade provisória. Rio de Janeiro: Forense, 1981. p. 59) que, com a possibilidade de concessão de liberdade provisória, nos casos em que a prisão preventiva se mostrava desnecessária, "atingimos a plenitude do liberalismo em matéria de liberdade individual".

6 FERRAJOLI, Luigi. Diritto e ragione: teoria del garantismo penale. 5. ed. Bari: Laterza, 1998. p. 808.

7 Embora com vista ao processo cautelar, e não propriamente à tutela cautelar, sua autonomia é reconhecida em doutrina: LIEBMAN, Enrico Tullio. Unità del procedimento cautelare. Problemi del processo civile. 
preveja medidas que possibilitem tal tipo de tutela para assegurar a efetividade da tutela jurisdicional.

Normalmente, são apontadas como características da tutela cautelar, com alguma variação, a assessoriedade, a preventividade, a sumariedade, a provisoriedade e a instrumentalidade hipotética. ${ }^{8}$

Porém, para a melhor compreensão das características da tutela cautelar, faz-se necessária uma comparação com a chamada tutela antecipada, principalmente à luz de suas finalidades.

Desde a Lei n. 8.952, de 13.12.1994, que modificou a redação do art. 273 do Código de Processo Civil, disciplinando a chamada tutela antecipada, surgiu um rico interesse da doutrina processual civil em analisar e procurar distinguir a tutela antecipada da tutela cautelar.

Ainda que de forma sucinta, diante do âmbito limitado desse trabalho, é de rigor expor as premissas em que se baseia a distinção entre tutela cautelar e tutela antecipada.

A tutela cautelar e a tutela antecipada têm a mesma razão de ser: eliminar ou ao menos minorar os males do tempo - e, entre nós, pode-se dizer - o longo tempo necessário para que o processo cumpra o seu desiderato de dar a quem tem um direito tudo aquilo e precisamente aquilo que o jurisdicionado tem o direito de obter. Ambas, pois, são filhas da demora processual. Daí, poderem ser consideradas espécies do gênero tutela de urgência. ${ }^{9}$

Napoli: Morano, [1962]. p. 110; CHIOVENDA, Giuseppe. Instituições de direito processual civil. Tradução de J. Guimarães Menegale. São Paulo: Saraiva, 1948. v. 1, p. 384; Principii di diritto processuale civile. 3. ed. Napoli: Jovene, 1965. p. 226; CARNELUTTI, Francesco. Diritto e processo. Napoli: Morano, 1958. p. 355. Ateriormente, CALAMANDREI, Piero. Introduzione allo studio sistematico dei provvedimenti cautelari. Padova: CEDAM, 1936, reproduzido In: Opere giuridiche. Napoli: Morano, 1983, v. IX), embora negando que o processo cautelar tivesse característica e estrutura autônoma (p. 164), já reconhecia a autonomia da função cautelar e do provvedimento cautelare em relação às tutelas de conhecimento e de execução. Na doutrina nacional, cf: LACERDA, Galeno. Comentários ao código de processo civil. 7. ed. Rio de Janeiro: Forense, 1998. v. VIII. t. I, p. 4.

8 Não é possível uma análise aprofundada de cada uma destas características. Para tanto, cf. SANCHES, Sydney. Poder cautelar geral do juiz no processo civil brasileiro. São Paulo: Revista dos Tribunais, 1978. p. 28-32. Como contraponto, cf. a profunda análise crítica de tais características feita por SILVA, Ovídio A. Batista da. As ações cautelares e o novo processo civil. 3. ed. Rio de Janeiro: Forense, 1980. p. 18-34. Para uma análise de tais características, na doutrina processual penal: RAMOS, João Gualberto Garcez. A tutela de urgência no processo penal brasileiro. Belo Horizonte: Del Rey, 1996, p. 86-95; LIMA, Marcellus Polastri. A tutela cautelar no processo penal. Rio de Janeiro: Lumen Juris, 2005. p. 68-76.

9 Cf.: DINAMARCO, Cândido Rangel. Instituições de direito processual civil. São Paulo: Malheiros, 2001. v. 1, p. 161; BEDAQUE, José Roberto dos Santos. Tutela cautelar e tutela antecipada: tutelas sumárias e de urgência (tentativa de sistematização). 3. ed. São Paulo: Malheiros, 2003. p. 158-159; OLIVEIRA, Carlos Alberto Álvaro de. Efetividade e processo cautelar. Revista de Processo, n. 76, out./dez. 1994, p. 92; THEODORO JÚNIOR, Humberto. Curso de direito processual civil. Rio de Janeiro: Forense, 1996. v. II, p. 370. 
A tutela cautelar tem por finalidade assegurar a utilidade e a eficácia de um provimento jurisdicional futuro. Ante o perigo da demora, até que seja concedida a tutela jurisdicional apta a satisfazer definitivamente a pretensão do autor, é necessário assegurar que tal provimento, a ser proferido em tempo futuro, não se torne inócuo devido à morosidade do processo. Trata-se, pois, de uma tutela assecuratória ou conservativa.

Já a tutela antecipada - diga-se, desde já, tutela antecipada em caráter provisório - também é vista como uma forma de eliminar os males da demora processual, mas não com vista a assegurar o resultado futuro, já propiciando ao jurisdicionado uma antecipação, total ou parcial, dos efeitos da tutela jurisdicional que será proferida em tempo ainda distante. Ou seja, antecipam-se os efeitos do provimento satisfativo a ser futuramente emitido para satisfazer, ainda que provisoriamente, os interesses do autor. Trata-se, pois de uma tutela satisfativa.

Em ambas, pois, há uma urgência que se traduz no pressuposto do periculum in mora. Há, porém, diferença da urgência em um ou outro caso. A doutrina italiana, embora com vistas às diversas espécies de tutela cautelar, de há muito distingue duas espécies de periculum in mora: de um lado, existe o periculo di infruttuosità, e de outro, o periculo di tardività. ${ }^{10}$ Ambos devem ser combatidos através de uma tutela de urgência. Se há perigo que o provimento definitivo seja "infrutuoso", isto é, que a tutela definitiva seja ineficaz, devem ser adotadas medidas conservativas. Já no caso em que o provimento futuro pode ser tardio, devem ser antecipados os efeitos de tal provimento. ${ }^{11}$

Em suma, tanto a tutela cautelar, quanto a tutela antecipada são provisórias, perdurando até que seja proferido outro provimento jurisdicional, que será definitivo e satisfativo. Há, portanto, elementos comuns em ambas, embora também apresentem diferenças específicas.

Prevalece, amplamente, na doutrina nacional, o entendimento que a tutela antecipada, por já ser apta a satisfazer o interesse do jurisdicionado, ainda que em caráter

\footnotetext{
${ }^{10}$ Cf.: por todos, PISANI, Andrea Proto. Lezioni di diritto processuale civile. 2. ed. Napole: Jovene, 1996. p. 660. Na doutrina nacional, cf.: BEDAQUE, José Roberto das Santos. op. cit., p. 171, nota 177. Embora sem usar tais expressões, merece destaca que posição de TORNAGHI, Hélio. Instituições de processo penal. 2. ed. São Paulo: Saraiva, 1978. v. 3. p. 7) que distingue o perigo de insatisfação e o risco da satisfação tardia: "a esses dois tipos de periculum in mora correspondem duas modalidades de providências acauteladoras: na primeira, o que se antecipa é a decisão de mérito, embora em caráter provisório; na outra, apenas se adiantam providências que tendem a preservar a instrução do processo (como no caso de apreensão de objetos destinados à prova), ou assegurar a execução (como no caso do arresto de bens do devedor)". Tal distinção é expressamente acolhida por BARROS, Romeu Pires de Campos. Processo penal cautelar. Rio de Janeiro: Forense, 1982. p. 185.

${ }^{11}$ PISANI, Andrea Proto. op. cit., p. 660. Na doutrina nacional, cf.: BEDAQUE, José Roberto das Santos. op. cit., p. 171.
} 
provisório, ${ }^{12}$ não tem natureza cautelar, que somente pode ter por escopo assegurar ou conservar a utilidade e a eficácia da tutela definitiva. ${ }^{13}$

Dinamarco explica que "para remediar situações aflitivas, a técnica processual excogitou certas medidas de urgência, caracterizadoras da tutela jurisdicional antecipada e da chamada tutela cautelar. Trata-se de técnicas teoricamente diferentes, endereçadas a situações diferentes, mas todas têm o comum objetivo de neutralizar os efeitos maléficos do decurso do tempo sobre os direitos. Existe uma diferença conceitual entre (a) as medidas que oferecem ao sujeito, desde logo, a fruição integral ou parcial do próprio bem ou situação pela qual litiga e (b) as medidas destinadas a proteger o processo em sua eficácia ou na qualidade de seu produto final. As primeiras, oferecendo situações favoráveis às pessoas na vida comum em relação com outras pessoas ou com os bens, integram o conceito de tutela jurisdicional antecipada. As segundas, qualificadas como medidas cautelares, resolvem-se em medidas de apoio ao processo - para que ele possa produzir resultados úteis e justos - e só indiretamente virão a favorecer o sujeito de direitos". 14

Em sentido contrário, destaca-se a posição de José Roberto dos Santos Bedaque que não vê incompatibilidade entre a tutela antecipada e a tutela cautelar:

\begin{abstract}
se ambas têm a mesma função no sistema e são estruturalmente provisórias, por que distingui-las? Inexiste razão histórica ou sistemática para não incluir as antecipatórias no rol das cautelares. A discussão acaba sendo meramente terminológica, pois temos duas categorias de tutelas não definitivas destinadas ambas a evitar que o tempo necessário à segurança jurídica acabe tornando inútil o resultado do
\end{abstract}

\footnotetext{
${ }^{12}$ Excepcionalmente, o sistema processual civil admite a ocorrência de uma tutela antecipada, baseada em cognição sumária, mas que seja definitiva e não provisória. Trata-se, do que (BEDAQUE, José Roberto das Santos. op. cit., p. 315) denomina "tutela sumária não cautelar", justamente por ter natureza satisfativa e definitiva, embora não seja precedida de uma cognição exauriente. Em regra, como o limite da cognição impede o pleno exercício do contraditório e do devido processo legal, a tutela antecipada não pode ser definitiva, nem terá aptidão para transitar em julgado materialmente. Excepcionalmente, contudo, devido à relevância do bem jurídico envolvido, e diante da particularidade da dupla irreversibilidade, isto é tanto a concessão quanto a não concessão da tutela antecipada produzirão efeitos irreversíveis sobre o direito material debatido, caberá ao julgador fazer um juízo de valor (cf.: ZAVACKI, Teori Albino. Antecipação de tutela e colisão de direitos fundamentais. In: TEIXEIRA, Sálvio de Figueiredo (Org.). Inovações do código de processo civil. São Paulo: Saraiva, 1996. p. 163; BEDAQUE, José Roberto das Santos. op. cit., p. 347). É o que ocorre, por exemplo, no caso em que a mãe pretende que o filho se submeta a uma intervenção cirúrgica, mas encontra oposição da marido, cuja religião não permite a realização de transfusão de sangue. Entre preservar o contraditório e o devido processo legal, de um lado, e preservar o direito material de alta relevância jurídica, de outro, este deve prevalecer. Trata-se, pois, de aplicação do princípio da proporcionalidade.

${ }^{13}$ Cf.: MARINONE, Luis Guilherme. Tutela cautelar e tutela antecipatória. São Paulo: Revista dos Tribunais, 1994. p. 79; OLIVEIRA, Carlos Alberto Álvaro de. op. cit., p. 92; THEODORO JÚNIOR, Humberto. op. cit., p. 370; DINAMARCO, Cândido Rangel. op. cit., p. 161. Na doutrina processual penal: RAMOS, João Gualberto Garcez. op. cit., p. 95.

${ }^{14}$ DINAMARCO, Cândido Rangel. op. cit., p. 161. (destaques no original).
} 
processo, com denominações diversas. Além disso, toda a doutrina reconhece outras características comuns a essas tutelas, como a cognição sumária, a precariedade e a referência a outra tutela, exatamente aquelas que determinam a natureza cautelar do provimento. Ora, se possuem tantos aspectos que as aproximam, melhor será tratá-las em conjunto e submetêlas ao mesmo regime jurídico. Esse parece ser o real interesse no estudo comparativo das espécies de tutelas provisórias, as de caráter meramente conservativo e as que possuem conteúdo antecipatório. Dada a similitude existente entre elas, aconselhável recebam o mesmo tratamento jurídico. Irrelevante considerá-las como modalidades de cautelar, ou reservar essa denominação apenas para a conservativa ou não antecipatória. Importante, sim, é determinar sua substância e demonstrar que ambas existem com a mesma finalidade e possuem características praticamente iguais. ${ }^{15}$

A divergência, realmente, parece ser terminológica e não de conteúdo: ambas correntes reconhecem a diferença entre medidas de urgência que, de um lado, conservam um estado de coisa, sem propiciar uma satisfação imediata e, de outro lado, medidas de urgência que antecipam efeitos práticos do futuro provimento, satisfazendo provisoriamente, pois, a pretensão do autor.

3. Prisão preventiva: tutela cautelar ou tutela antecipada?

Em sua grande maioria, a doutrina processual penal olvidou da distinção - mais terminológica do que de conteúdo - entre a tutela cautelar e a tutela antecipada. ${ }^{16}$ Tomando por empréstimo os conceitos processuais civis, cabe indagar se a prisão preventiva é uma tutela cautelar ou é uma tutela antecipada?

Ressalte-se, desde já, que, no campo processual penal, a questão não será meramente terminológica.

Diante da consagração expressa do princípio da presunção de inocência do Constituição de 1988, a doutrina processual penal, em sua ampla maioria, extraiu as seguintes conseqüências, quanto ao tratamento do acusado ao longo do processo: (1) a presunção de inocência não é incompatível com a prisão antes do trânsito em julgado, desde

\footnotetext{
15 BEDAQUE, José Roberto das Santos. op. cit., p. 300-301. Também (DINAMARCO, Cândido Rangel. op. cit., p. 163), embora entendendo tratar-se de tutelas distintas, que seriam espécies do gênero tutela de urgência, destaca que: "assim contidas numa categoria unitária, as medias cautelares e as antecipações de tutela regemse por uma disciplina também unitária, que só em pontos muito específicos se bifurcam em regras privativas de cada uma das espécies" (destaque no original).

16 Apresentando a preocupação de analisar as medidas cautelares processuais penais em confronto com a tutela antecipada: RAMOS, João Gualberto Garcez. op. cit., p. 95; LIMA, Marcellus Polastri. A tutela cautelar no processo penal. Rio de Janeiro: Lumne Juris, 2005. p. 62-68.
} 
que tal prisão tenha natureza cautelar; (2) é incompatível com a presunção de inocência qualquer forma de prisão antes do trânsito em julgado, que constitua execução penal provisória ou antecipada. ${ }^{17}$ Em outras palavras: a prisão preventiva será legal e legítima se tiver natureza cautelar, mas não poderá constituir uma antecipação da condenação penal.

Diante de tais premissas, parece claro que somente será compatível com o estado de inocência medidas cautelares propriamente ditas, isto é, prisões processuais que tenham natureza conservativa. De outro lado, não será legítima qualquer prisão anterior ao trânsito em julgado da sentença penal condenatória que tenha por finalidade antecipar total ou parcialmente os efeitos da condenação penal e, portanto, seja mesmo que provisoriamente, satisfativa.

Cabe aqui, pois, a seguinte indagação: a prisão preventiva visa conservar a utilidade e eficácia do provimento futuro a ser proferido na ação penal condenatório (tutela cautelar conservativa) ou tem por finalidade antecipar efeitos práticos da sentença condenatória (tutela antecipada)?

Tendo por critério a situação fática ou os efeitos práticos da prisão preventiva, poder-se-ia facilmente concluir tratar-se de uma hipótese de antecipação de tutela. ${ }^{18}$ Os efeitos práticos da prisão preventiva são em tudo semelhantes aos efeitos práticos da prisão para o cumprimento de pena privativa de liberdade. ${ }^{19}$ Aliás, muitas vezes são até mais severos, como no caso em que o preso cautelar se encontra numa cadeia pública ou num centro de detenção provisória, em uma situação semelhante a de quem esteja cumprindo pena em regime fechado, malgrado lhe venha a ser imposta uma pena privativa de liberdade em regime semi-aberto. ${ }^{20}$

${ }^{17}$ Com explica GOMES FILHO, Antonio Magalhães. Presunção de inocência e prisão cautelar. São Paulo: Saraiva, 1991. p. 43) diante da presunção de inocência, "antes da sentença final, toda antecipação de medida punitiva ... viola esse princípio fundamental" sendo, pois, "inconciliável com o princípio constitucional qualquer forma de execução provisória do julgado penal".

${ }^{18}$ Como destaca (BEDAQUE, José Roberto das Santos. op. cit., p. 145) “os efeitos porventura antecipados são aqueles fáticos ligados à tutela final. A eficácia jurídica da tutela declaratória, condenatória ou constitutiva, representada pelas conseqüências operadas no ordenamento material, não integra o provimento antecipatório". No mesmo sentido, (ZAVASCKI, Teori Albino. Antecipação da tutela. 5. ed. São Paulo: Saraiva, 2005. p. 48) afirma que "antecipa-se a eficácia que a futura sentença pode produzir no campo da realidade dos fatos".

19 Justamente por haver esta similitude prática, é que o art. 42 do CP prevê a detração da prisão cautelar em relação à pena privativa de liberdade.

${ }^{20}$ Justamente para procurar minorar os efeitos da demora e da irrazoável duração do processo, em especial na fase recursal, a praxis judiciária acabou consagrando o que veio a ser denominado "execução penal provisória", em favor do condenado. Isto é, a aplicação ao preso provisório, que já tenha sido julgado e a sentença condenatória tenha transitado em julgado para a acusação, dos institutos da lei de execução penal, como a progressão de regime e o livramento condicional. Tal movimento culminou com a edição da Súmula n. 716 do STF: "Admite-se a progressão de regime de cumprimento da pena ou a aplicação imediata de regime menos severo nela determinada, antes do trânsito em julgado da sentença condenatória”. 
Porém, ao se ter em conta o escopo ou a finalidade que orienta a decretação da medida, percebe-se que a prisão preventiva tem natureza conservativa e, portanto, tipicamente, cautelar. ${ }^{21}$

Analisando os requisitos da prisão preventiva, previstos no art. 312 do CPP, identificados pela doutrina como situações de periculum libertatis, encontram-se as hipóteses em que a prisão se faz necessária.

Principia-se pela prisão para "assegurar a aplicação da lei penal". Nesse caso, a prisão é necessária para “evitar que, diante da possível fuga do acusado, pelo temor da condenação, venha a ser frustrada a futura execução da sanção punitiva". ${ }^{22} \mathrm{O}$ perigo de fuga ocorre quando o investigado ou o acusado "prepara-se para deixar o seu domicílio, desfazendo-se dos bens imóveis, demonstrando o desejo de empreender viagem ou revela a outrem esse seu propósito". ${ }^{23}$ Trata-se, claramente, de uma hipótese de prisão cautelar pelos fins a que se destina. Assegurar a utilidade e a eficácia de um provimento condenatório que se mostra provável, diante do fumus commissi delicti. Tal situação tem sido denominada como prisão cautelar final. ${ }^{24}$

Também é cautelar a prisão preventiva decretada "por conveniência da instrução criminal". ${ }^{25}$ Sua necessidade surge quando o acusado está ameaçando ou subornando testemunhas ou peritos, ocultando ou destruindo provas, ou buscando furtarse ao comparecimento a atos de instrução em que sua presença seja necessária, como no reconhecimento pessoal. ${ }^{26}$ Trata-se de prisão cautelar instrumental. ${ }^{27}$ Sua finalidade não é diretamente assegurar a eficácia do resultado final do processo em si (p. ex.: evitar a fuga

${ }^{21}$ Com já ressalta (BATISTA, Weber Martins. op. cit., p. 46) "no mundo inteiro, como se expôs, os processualistas reclamam a prova da necessidade, como pressuposto indispensável para que a prisão provisória seja decretada ou mantida. Necessidade para conseguir os fins do processo" (destaques nossos). Corretíssima a observação de (RAMOS, João Gualberto Garcez. op. cit., p. 96) de que a satisfatividade, para configurar a tutela antecipatória, deve ser o escopo da medida de urgência: "Será antecipatória aquela medida preordenada à satisfação antecipada da pretensão de direito material e não aquela que, quase que acidentalmente, acaba por antecipá-la. Daí se poder referir que o fenômeno, nesse caso, é de satisfatividade teleológica e não meramente conseqüencial" (destaque no original).

22 GOMES FILHO, Antonio Magalhães. op. cit., p. 71.

${ }_{23}$ BARROS, Romeu Pires de Campos. op. cit., p. 201.

${ }^{24}$ Cf.: MARQUES, José Frederico. Elementos de direito processual penal. Rio de Janeiro: Forense, 1965. v. IV, p. 49; BATISTA, Weber Martins. op. cit., p. 76; GOMES FILHO, Antonio Magalhães. op. cit., p. 72.

25 Embora reconhecendo o caráter cautelar, a doutrina destaca o caráter ingênuo (porque não impede a destruição das provas) e prejudicial (porque impede o pleno exercício do direito de defesa). Nesse sentido: BATISTA, Weber Martins. op. cit., p. 75-76; GOMES FILHO, Antonio Magalhães. op. cit., p. 70-71.

${ }^{26}$ Cf.: BARROS, Romeu Pires de Campos. op. cit., p. 201; BATISTA, Weber Martins. op. cit., p. 75; GOMES FILHO, Antonio Magalhães. op. cit., p. 70;

${ }^{27}$ Cf.: MARQUES, José Frederico. op. cit., p. 50; BATISTA, Weber Martins. op. cit., p. 77; GOMES FILHO, Antonio Magalhães. op. cit., p. 69. Embora trata-se de uma medida cautelar de prisão preventiva, para assegurar a prova, por óbvio, tal medida não se confunde com outro tipo de medida cautelar, consistente na produção antecipada de prova, como prevê o art. 225 do CPP. Na doutrina processual civil (CALAMANDREI, Piero. op. cit., p. 180) já se referia às medidas cautelares consistente em provimentos instrutórios antecipados. 
que impediria o cumprimento a sentença), mas sim conservar os meios ou instrumentos (provas) para que se possa chegar a tal resultado (sentença condenatória).

Finalmente, para a análise da prisão preventiva para "garantia da ordem pública", merecem ser transcritas as irretocáveis palavras de Antonio Magalhães Gomes Filho:

à ordem pública relacionam-se todas aquelas finalidades do encarceramento provisório que não se enquadram nas exigências de caráter cautelar propriamente ditas, mas constituem formas de privação de liberdade adotadas como medidas de defesa social; fala-se, então, em 'exemplaridade', no sentido de imediata reação ao delito, que teria como efeito satisfazer o sentimento de justiça da sociedade; ou, ainda, em prevenção especial, assim entendida a necessidade de se vitar novos crimes; uma primeira infração pode revelar que o acusado é acentuadamente propenso a práticas delituosas ou, ainda, indicar a possível ocorrência de outras, relacionadas à supressão de provas ou dirigidas contra a própria pessoa do acusado. Parece evidente que nessas situações a prisão não é um 'instrumento a serviço do instrumento', mas uma antecipação da punição, ditada por razões de ordem substancial e que pressupõe o reconhecimento da culpabilidade. $^{28}$

Em suma, quando se prende para "garantir a ordem pública" não se está buscando a conservação de uma situação de fato necessária para assegurar a utilidade e a eficácia de um futuro provimento condenatório. Ao contrário, o que se está buscando é a antecipação de alguns efeitos práticos da condenação penal. ${ }^{29}$ No caso, priva-se o acusado

${ }^{28}$ GOMES FILHO, Antonio Magalhães. op. cit., p. 67-68. No mesmo sentido, também merecendo transcrição, o posicionamento de SANGUINÉ, Odone. Clamor público como fundamento da prisão preventiva. In: SHECAIRA, Sérgio Salomão (Org.). Estudos criminais em homenagem a Evandro Lins e Silva: criminalista do século. São Paulo: Método, 2001. p. 258-259 "quando se argumenta com razões de exemplaridade, de eficácia da prisão preventiva na luta contra a delinqüência e para restabelecer o sentimento de confiança dos cidadãos no ordenamento jurídico, aplacar o clamor público criado pelo delito, etc., que evidentemente nada tem a ver com os fins puramente cautelares e processuais que oficialmente se atribuem à instituição, na realidade se introduzem elementos estranhos à natureza cautelar e processual que oficialmente se atribuem à instituição, questionáveis tanto desde o ponto de vista jurídico-constitucional como da perspectiva políticocriminal. Isso revela que a prisão preventiva cumpre 'funções reais' (preventivas gerais e especiais) de pena antecipada incompatíveis com sua natureza".

${ }^{29}$ (MARQUES, José Frederico. op. cit., p. 49-50) afirma que em tal caso a "prisão preventiva perde seu caráter de providência cautelar, constituindo antes, verdadeira "medida de segurança'”. Para DELMANTO JR., Roberto. As modalidades de prisão provisória e seu prazo de duração. Rio de Janeiro: Renovar, 1998. p. 156) trata-se de prisão que serve "de instrumento de justiça sumária, vingança social, etc...", além de implicar presunção de culpabilidade. De forma semelhante, LOPES JÚNIOR, Aury. Introdução crítica ao processo penal: fundamentos da instrumentalidade garantista. 3. ed. Rio de Janeiro: Lumen Juris, 2005. p. 208) a prisão para garantia da ordem pública não é cautelar, transformando-se em atividade tipicamente de polícia, utilizando-as indevidamente como medidas de segurança pública" (destaque no original). Em sentido parcialmente diverso, 
de sua liberdade, ainda que juridicamente tal situação não seja definitiva, mas provisória, é uma forma de tutela antecipada, que propicia uma execução penal antecipada. Exatamente esse o sentido do art. 393, inc. I, do CPP, que prevê, entre os efeitos da sentença penal condenatória recorrível, "ser o réu preso ou conservado na prisão".

Finalmente, resta analisar a prisão para garantia da ordem econômica, ${ }^{30}$ que tem sido identificada com situações de crimes que envolvam vultosos golpes no mercado financeiro, ${ }^{31}$ abalando a credibilidade na ordem econômica ou do sistema financeiro. ${ }^{32}$ Parte da doutrina, inclusive, vê em tal hipótese uma espécie da prisão para garantia da ordem pública, considerando até mesmo desnecessário o acréscimo legislativo. ${ }^{33}$ A prisão para garantia da ordem econômica não é, tal qual aquela para garantia da ordem pública, uma medida cautelar. Não se destina a ser um instrumento para assegurar os meios (cautela instrumental) o ou resultado do processo (cautela final). Ao contrário, sua finalidade é permitir uma execução penal antecipada, visando fins de prevenção geral e especial, próprios da sanção penal, mas não das medidas cautelares. ${ }^{34}$

Em suma, segundo os critérios do Código de Processo Penal, ${ }^{35}$ a prisão preventiva tem natureza cautelar, ou seja, é medida com finalidade conservativa, nos casos

RAMOS, João Gualberto Garcez. op. cit., p. 143, considera que "a prisão preventiva decretada por garantia da ordem pública não é cautelar nem antecipatória, mas medida judiciária de polícia, justificada e legitimada pelos altos valores sociais em jogo". De qualquer forma, não sendo cautelar, a restrição à liberdade, antes do trânsito em julgado da condenação, mesmo que a ela se pretenda dar a natureza de medida judiciária de polícia, mostra-se incompatível com a garantia constitucional da presunção de inocência. Aliás, FERRAJOLI, Luigi. op. cit., p. 808-809, desta o tratamento inconfundivelmente policialesco da prisão preventiva, e conclui: "prima si punisce e poi si processa".

${ }^{30}$ A Lei n. 8.884, de 11.06.1994 alterou a redação do art. 312 do CPP, para acrescentar a possibilidade de prisão preventiva para a garantia da ordem econômica.

${ }^{31}$ DELMANTO JÚNIOR, Roberto. op. cit., p. 164.

${ }_{32}$ Para TOURINHO FILHO, Fernando da Costa. Processo penal. 22. ed. São Paulo: Saraiva, 2000. v. 3, p. 491, tal prisão poderia ocorrer no caso dos crimes previsto no art. $4^{\circ}$, inc. IV e VII da Lei n. 8.137/90. De forma mais ampla MIRABETTE, Julio Fabbrini. Processo penal. 16. ed. São Paulo: Atlas, 2004. p. 418, refere-se aos crimes do "art. 20 da Lei n. 8884/94, como os das Lei ns. 8.137, 7.492/86, 1.521/52, etc".

${ }^{33}$ Cf.: TOURINHO FILHO, Fernando da Costa. op. cit., p. 491; RAMOS, João Gualberto Garcez. op. cit., p. 144.

${ }^{34}$ Cf.: DELMANTO JÚNIOR, Roberto. op. cit., p. 156; LOPES JÚNIOR, Aury. op. cit., p. 208. Uma vez mais, destaque a posição de RAMOS, João Gualberto Garcez. op. cit., p. 145 considera que a prisão preventiva decretada por garantia da ordem econômica não é cautelar nem antecipatória, mas medida judiciária de policia.

${ }^{35}$ Nos crimes contra o sistema financeiro - Lei n. 7.492/86, art. 30 - é possível a decretação da prisão preventiva diante da "magnitude da lesão". A toda evidência, tal critério não guarda relação com a urgência da medida. Não se trata de prisão cautelar, posto que não se destina a conservar uma situação de fato. É perfeitamente possível que a lesão seja de grande magnitude, mas a prisão não se mostre necessária, posto que não há perigo de que a sentença final seja "tardia". Por outro lado, nem mesmo o perigo de "infruttuosità" estará presente. É perfeitamente possível que a prisão seja decretada sem que haja necessidade de se antecipar algum efeito prático da condenação. Aliás, se a "magnitude da lesão" ao bem penalmente tutelado fosse situação indicativa da necessidade da prisão, deveria ser aplicado os demais delitos e, nesse caso, por exemplo, num crime de homicídio, a "magnitude da lesão causada" (a morte), sempre justificaria a prisão. Na prática, seria ressuscitar a prisão preventiva obrigatória, prevista no art. 312 do CPP, em sua redação originária. De forma semelhante, 
em se mostra necessária para "assegurar a aplicação da lei penal” (cautela final) e para a "conveniência da instrução criminal" (cautela instrumental). ${ }^{36}$ Por outro lado, tem natureza de tutela antecipada nos casos em que é decretada para "garantia da ordem pública", posto que sua finalidade não será conservar um estado de fato, para assegurar a utilidade e a eficácia da sentença condenatória, mas sim antecipar alguns dos efeitos práticos da pena, no caso, privar o acusado de sua liberdade. ${ }^{37}$

4. A proporcionalidade da prisão preventiva com a pena provável a ser aplicada

Toda medida cautelar deve guardar conexão com o provimento futuro que a irá substituir. Em outras palavras, a medida cautelar sempre deve ter em vista uma medida satisfativa e definitiva, resultado do reconhecimento do direito debatido no processo principal, que exige tempo para ser reconhecido. ${ }^{38}$ Transportando esses conceitos para o processo penal, pode-se dizer com Cordero que, "medida cautelar e quantificação da pena são termos correlativos". 39

E, embora a prisão preventiva, do ponto de vista teleológico, não seja uma "pena antecipada", como adverte Maurach, o mal real causado pela prisão preventiva deve ser parecido, quanto aos efeitos realmente produzidos, aos da pena. ${ }^{40} \mathrm{Na}$ prisão preventiva,

RAMOS, João Gualberto Garcez. op. cit., p. 146, nega a natureza cautelar para tal prisão, pelo que a considera inconstitucional.

${ }^{36}$ A distinção entre cautela instrumental e cautela final corrente na doutrina italiana: CARNELUTTI, Francesco. Lecciones sobre el proceso penal. Tradução de Santiago Sentís Melendo. Buenos Aires: Ejea,1950. v. II, p. 72; GREVI, Vittorio. Libertà personale dell'imputato. Enciclopedia del Diritto, Milano, 1974. v. 24, p. 336.

37 A tal conclusão já havia chegado BATISTA, Weber Martins. op. cit., p. 16: "Nas duas últimas hipóteses, temos verdadeiras medidas cautelares. Garantir a colheita da prova e assegurar a presença do réu para o eventual cumprimento da pena são medidas tomadas no interesse do processo, sendo, pois, evidente o seu caráter instrumental. $\mathrm{O}$ mesmo não se diga da decretação da providência como garantia da ordem pública. Nesse caso, a medida não guarda relação direta com o processo. Em vez disso, está voltada para a proteção de interesses a ele estranhos, tem nítido traço de medida cautelar de segurança". No mesmo sentido: GOMES FILHO, Antonio Magalhães. op. cit., p. 68, 70 e 71; TOURINHO FILHO, Fernando da Costa. op. cit., p. 521; DELMANTO JÚNIOR, Roberto. op. cit., p. 148 e 156.

${ }^{38}$ Com explica BEDAQUE, José Roberto das Santos. op. cit., p. 182, "à exceção da cautelar destinada a antecipar atos de produção de prova, toda as demais modalidades exigem do juiz exame da relação e direito material, ainda que de forma superficial".

${ }^{39}$ CORDERO, Franco. Procedura penale. Milano: Giuffrè, 2000. p. 475. No mesmo sentido, GREVI, Vittorio. Misure cautelari. In: CONSO, Giovanni; GREVI, Vittorio(Orgs.). Profili del nuovo codice di procedura penale. Padova: Cedam, 1996. p. 299, analisando o princípio da proporcionalidade, refere-se a uma "congruità (sotto il profilo della deminutio libertatis che ne direva all'imputato) rispetto alla gravità del fatto addebitattogli e, quindi, al quantum di pena che in concreto (alla luce della complessiva situazione processuale) possa essergli irrogato" (destaques no original).

${ }^{40}$ MAURACH, Reinhart. Tratado de derecho penal. Tradução de Juan Córdoba Roda. Barcelona, v. II, 1962, p. 551, apud BATISTA, Weber Martins. op. cit., p. 10. 
o acusado não deve pagar um preço que ele provavelmente não será chamado a pagar nem mesmo depois da condenação. ${ }^{41}$

Há, pois, um princípio de proporcionalidade que governa as medidas cautelares e, em especial, a prisão cautelar. ${ }^{42}$

Conseqüência disso é que o juiz não deve se limitar a analisar "prova da existência do crime e indício suficiente de autoria" para a decretação da prisão preventiva (CPP, art. 312). Esses critérios são indicadores do denominado fumus commissi delicti, isto é, da probabilidade, baseada em uma cognição sumária, de que o acusado seja o autor de um delito. São elementos necessários, mas não suficientes para a prisão cautelar. ${ }^{43}$

A análise do "direito hipotético" não deve se limitar a "probabilidade de uma condenação". Há mais a ser considerado nesse juízo prognóstico. O juiz deverá também considerar a probabilidade de que seja imposta uma pena privativa de liberdade a ser executada. ${ }^{44}$ Somente no caso em que se anteveja, com base nos elementos concretos existentes nos autos, que o acusado terá que se submeter a uma a pena privativa de liberdade, a prisão cautelar será proporcional ao provimento definitivo que ela visa assegurar.

Caso o juiz anteveja que a pena a ser imposta será apenas uma pena de multa, ${ }^{45}$ ou uma pena privativa de liberdade que será substituída por pena restritiva de direito, ou ainda, uma pena privativa de liberdade que será condicionalmente suspensa

${ }^{41}$ ZAPPALÀ, E. Le misure cautelari. Diritto processuale penale. 2. ed. Milano: Giuffrè, 1996. v. 1, p. 447.

${ }^{42}$ Obviamente, a proporcionalidade não é o único princípio aplicável á prisão cautelar. BERTOLINO, Pedro Juan. Código procesal penal de la Província de Buenos Aires (Ley 11.922) comentado y concordado. 5. ed. Buenos Aires: Depalma, 1998. p. 174, explica que; "se puede señalar como principios basilares que disciplinan las medidas de coerción: a) 'adecuación', que guarda relación con cuál medida debe ser aplicada la coerción; b) 'proporcionalidade', que debe guardar la medida, sobre todo, con la pena que se debe aplicar; c) 'subsidiariedad', que dice relación con el usar siempre la medida menos gravosa; d) 'excepcionalidad', que vincula medio a fin; es decir, no se debe decretar la medida restrictiva si los fines buscados pueden ser obtenidos por otros medios".

${ }^{43}$ Nesse sentido, cf.: GREVI, Vittorio. Libertà personale dell'imputato. In: ENCICLOPEDIA del Diritto. Milano: Giuffrè, 1974. v. 24. p. 340. De forma semelhante, LOPES JÚNIOR, Aury. op. cit., p. 206, analisando a proporcionalidade, como um dos princípios que governa as prisões cautelares, afirma que o juiz, diante do caso concreto, "deverá ponderar a gravidade da medida imposta com a finalidade pretendida, sem perder de vista a densidade do fumus commissi delicti e do periculum libertatis".

${ }^{4}$ Antes mesmo do CPP de 1988 tal aspecto já era destacado por GREVI, Vittorio. Libertà personale dell 'imputato. cit., p. 340; Na doutrina nacional: BENETTI, Sidnei. Prisão provisória: direito alemão e brasileiro. Revista dos Tribunais, São Paulo, n. 669, p. 272- 1991; GOMES FILHO, Antonio Magalhães. op. cit., p. 72; SANGUINÉ, Odone. Prisão provisória e princípios constitucionais. In: Fascículos de ciências penais. Porto Alegre: Sérgio Fabris, 1992. v. 5, n. 2, p. 100; GRECO FILHO, Vicente. Manual de processo penal. 6. ed. São Paulo: Saraiva, 1999. p. 275-276; RAMOS, João Gualberto Garcez. op. cit., p. 115; FERNANDES, Antonio Scarance. Processo penal constitucional. 4. ed. São Paulo: Revista dos Tribunais, 2005. p. 57; ARAÚJO, Sérgio Luiz Souza. Teoria geral do processo penal. Belo Horizonte: Mandamentos, 1999. p. 388; LIMA, Marcellus Polastri. op. cit., p. 261-262.

45 Embora analisando a hipótese de liberdade provisória em que o preso se livra solto, BATISTA, Weber Martins. op. cit., p. 43-44, afirma que, na hipótese em que o crime é punido tão-somente com pena de multa, “em razão da pequena importância da infração cometida, é desproporcional a gravidade da providência cautelar consistente na restrição máxima da liberdade do processado, não justifica sua imposição" (destaque nosso). 
(sursis) ${ }^{46}$ ou, finalmente, uma pena privativa de liberdade a ser cumprida em regime aberto, será ilegal a decretação da prisão preventiva, posto que desproporcional ao resultado final do processo cuja utilidade se quer assegurar. ${ }^{47}$

Se a medida cautelar, no caso a prisão preventiva, for mais gravosa que a pena a ser ao final imposta, não será dotada do caráter de instrumentalidade e acessoriedade inerentes à tutela cautelar. Mesmo no que diz respeito à provisoriedade, não se pode admitir que a medida provisória seja mais severa que a medida definitiva que a irá substituir e a qual ela deve preservar.

Em diversos dispositivos o CPP acolhe o princípio da proporcionalidade em relação à prisão preventiva. $\mathrm{O}$ art. 313 estabelece requisitos da prisão preventiva relacionados com a pena do delito. A regra é a decretação da prisão preventiva em crimes punidos com reclusão (inc. I). Interpretando a contrário senso tal dispositivo, não se decreta a prisão preventiva em contravenções penais ou em crimes culposos (caput). ${ }^{48}$ Também não é possível a prisão preventiva em crimes punidos com detenção, ${ }^{49}$ salvo, neste último caso, se o acusado é vadio ou há dúvida sobre sua identificação (inc. II) ou é reincidente em crime doloso (inc. III). ${ }^{50}$ Nos crimes punidos com reclusão não há restrições para a decretação da prisão preventiva.

Observamos, contudo, que essa desproporção não ocorre somente em vista da pena cominada, mas também tendo em vista a provável pena a ser aplicada.

${ }^{46}$ No CPP italiano, o art. 275, n. 2-bis, introduzido pela Lei n. 332, de 8 de agosto de 1995, estabelece que: "Non può essere disposta la misura della custodia cautelarere se il giudice ritiene che con la sentenza possa essere concessa la sospensione condizionale della pena". Na doutrina nacional: FERNANDES, Antonio Scarance. op. cit., p. 57. GREVI, Vittorio. op. cit., p. 340, vai além, afirmando que deve ser considerada, também, a possibilidade de concessão de perdão judicial, anistia ou indulto, como fatores demonstradores da desproporcionalidade.

${ }^{47}$ De forma semelhante, mas sem afirmar a impossibilidade de decretação da prisão, para (DELMANTO JÚNIOR, Roberto. op. cit., 142-143) o juiz "deverá estar bastante atento à eventual desproporcionalidade e à excepcionalidade da prisão preventiva”. Embora referindo-se à razoabilidade ao invés de proporcionalidade, mas substancialmente com o mesmo conteúdo acima defendido, merece destaque o seguinte julgado: "Ademais, havendo condenação, não é desmensurado vislumbrar a fixação de regime aberto para o cumprimento da pena, ou eventualmente semi-aberto, tornando implausível, sob pena de ofensa ao princípio da razoabilidade, a prisão processual, eis que haveria encarceramento próprio ao regime fechado, o que, no panorama fático relatado, mostra-se injustificável" (TRF 4 Região, HC n. 2002.04.01.011925-2/RS, 8 Turma, Rel. Des. Fed. Élcio Pinheiro de Castro, j. 29.04.2002, v.u.).

${ }^{48}$ Em relação à contravenção penal e o crime culposo, (DELMANTO JÚNIOR, Roberto. op. cit., p. 142) observa que "tal prisão seria absolutamente desproporcional" (destaques nosso). De forma semelhante, (BARROS, Romeu Pires de Campos. op. cit., p. 202), comentando o art. 313 do CPP, explica que "não teria sentido que a prisão preventiva fosse admitida pela prática de qualquer infração penal, mesmo as não sancionadas com pena privativa de liberdade".

${ }^{49}$ NUCCI, Guilherme de Souza. Código de processo penal comentado. 5. ed. São Paulo: Revista dos Tribunais, 2006. p. 616, após destacar a desproporção da medida, afirma que "indica a lei que não é admissível a decretação da prisão preventiva, nesses casos, até porque as penas a eles impostas serão brandas, passíveis de substituição por penas alternativas, tornando eventual segregação excessiva".

${ }^{50} \mathrm{O}$ art. 42 da Lei n. 11.340, de 07.08.2006, que visa a combater a violência doméstica e familiar contra a mulher, acrescentou um inc. IV ao art. 313 do CPP, admitido a prisão preventiva "se o crime envolver 
A mesma preocupação entre a proporcionalidade da pena que se projeta na condenação e a prisão cautelar inspirou o instituto da liberdade provisória sem fiança e sem vínculos, em que o acusado se livra solto (CPP, art. 321), embora se trate de alternativa à prisão em flagrante delito, e não-requisito para a decretação da prisão preventiva. $\mathrm{O}$ mesmo se diga quanto à possibilidade de fiança para os crimes punidos com pena mínima cominada de até dois anos (CPP, art. 323, inc. I). E, com maior razão, para a previsão de não se impor prisão em flagrante delito, no caso de infração penal de menor potencial ofensivo, ${ }^{51}$ ao autor do fato que for imediatamente encaminhado ao juizado ou assumir o compromisso de a ele comparecer (Lei n. 9.099/95, art. 69, parágrafo único).

Todas essas regras, porém, hoje se mostram insuficientes.

Com as mudanças introduzidas no CP pela Lei n. 9.714, de 25.11.1998, mesmo nos crimes punidos com reclusão, desde que não sejam cometidos com violência ou grave ameaça à pessoa, se a pena privativa de liberdade aplicada - e não a pena cominada - for de até 4 anos, poderá ser substituída por restritiva de direitos e multa, ou por duas penas restritivas de direito (CP, art. 44). De qualquer forma, o condenado não será levado à prisão para cumprir sua pena.

Por outro lado, se a pena mínima cominada for de até 1 ano, pouco importando a pena máxima, mesmo que o crime seja cometido com violência ou ameaça à pessoa, é possível, satisfeitos os demais requisitos legais, a obtenção da suspensão condicional do processo, que poderá levar a extinção da punibilidade, sem que haja necessidade de desenvolvimento do processo penal e, conseqüentemente, de sentença penal.

Como adverte Fernando da Costa Tourinho Filho:

o juiz hoje, principalmente diante dessas leis imperfeitas e que suscitam escárnio, em face do seu grotesco e ridículo, não pode despreocupar-se da sorte do cidadão e, sem maior exame, aplicar a lei, sem calcular, antes as suas conseqüências nefastas. Já se disse que a Justiça não é uma arte, mas uma

violência doméstica e familiar contra a mulher, nos termos da lei específica, para garantir a execução das medidas protetivas de urgência". Tal regra deve ser interpretada com cuidado, para evitar a imposição de uma prisão preventiva desproporcional. Há caso de violências físicas gravíssimas, em que o acusado deverá ser sancionado com pena privativa de liberdade, sem direito a sursis ou qualquer outro benefício. Em tal hipótese, a prisão preventiva, presente os demais requisitos, será necessária, adequada e proporcional. Mas, por outro lado, há situações de lesões corporais leves, mesmo que qualificadas por se tratar de violência doméstica (CP, art. 128, $\S 9^{\circ}$, acrescido pelo art. 44 da referida lei) que, admitem, em tese, a suspensão condicional do processo (CP, art. 77) Em tais hipóteses, a imposição de uma prisão preventiva não estará assegurando a utilidade e a eficácia da futura sentença penal. Se a pena privativa de liberdade vai ter seu cumprimento suspenso, a prisão cautelar será excessiva, desproporcional e ilegal.

51 Diante da nova que a Lei n. 11.313, de 28.06.2006 deu ao art. 61 da Lei n. 9.099, de 26.09.1995, "Consideramse infrações penais de menor potencial ofensivo, para os efeitos desta Lei, as contravenções penais e os crimes a que a lei comine pena máxima não superior a 2 (dois) anos, cumulada ou não com multa", ressaltando-se que não há mais a restrição do requisito negativo da não previsão de procedimento especial. 
ciência de bem fazer. Ante a dúvida, a interpretação deve ser a favor da liberdade. ${ }^{52}$

É hora, portanto, de se dar um passo adiante. A proporcionalidade não deve ser buscada somente tendo em vista a pena cominada ao delito, mas considerando-se a pena que provavelmente será aplicada, ainda que com base em uma cognição sumária.

Vicente Greco Filho, depois de negar a possibilidade da prisão para assegurar a aplicação da lei penal, em caso de pena de multa, observa que:

em princípio, somente pode ser decretada a preventiva se houver prognóstico de cumprimento efetivo de pena privativa de liberdade. Os requisitos dos benefícios penais, como a suspensão condicional da pena, ou a prisão albergue, podem não coincidir com a necessidade da prisão processual, mas, em princípio, se há prognóstico fundado da concessão de um desses benefícios e não há outro motivo legal autônomo (como, por exemplo, ofensa à ordem pública por ameaça a testemunhas), a preventiva não deve ser decretada. Isso porque, salvo motivo independente, não há razão de prisão processual se, condenado definitivamente, esta não se efetivará. ${ }^{53}$

Concordamos integralmente com a premissa, apenas discordando da possibilidade de se decretar a preventiva, mesmo quando não haja prognóstico de pena privativa de liberdade a ser cumprida, desde que ocorra um fundamento autônomo (cautela instrumental $^{54} \mathrm{e}$, para quem admite, garantia da ordem pública). Em nenhuma hipótese e por nenhum dos motivos que caracterizam o periculum libertatis, pode se decretar a prisão preventiva se não há prognóstico de cumprimento efetivo de pena privativa de liberdade.

Considerando a hipótese da prisão preventiva como cautela instrumental, isto é, como medida para assegurar a integridade das provas para apuração de uma contravenção penal ou um crime de pequena gravidade, é de se considerar que eventuais condutas deverão ser evitadas pelo Estado por outros meios, que não a desproporcional prisão preventiva. Cabe ao Estado, por outros meios, prevenir a destruição e inutilização

\footnotetext{
52 TOURINHO FILHO, Fernando da Costa. Processo penal. 22. ed. São Paulo: Saraiva, 2000. v. 3, p. 543.

${ }^{53}$ GRECO FILHO, Vicente. Manual de processo penal. 6. ed. São Paulo: Saraiva, 1999. p. 275-276. Referido posicionamento é, expressamente, acolhido por ARAÚJO, Sérgio Luiz Souza. op. cit., p. 388; LIMA, Marcellus Polastri. op. cit., p. 261-262.

${ }^{54}$ Em sentido contrário, embora se referindo especificamente à impossibilidade de decretação da prisão, quando o juiz considere que na sentença possa ser concedida a suspensão condicional da pena, (GREVI, Vittorio. op. cit., p. 299) considera que tal norma foi “ispirata ad una concezione pressoché esclusivamente sostanzialistica della custodia cautelare (quasi si trattasse di uma sorte di 'antecipazione della pena', peraltro contra legem); ma trascura, nel contempo, l'eventuale profilarsi di esigenze cautelari di natura probatoria, che potrebero, invece, concretamente sussistere in grado tale da rendere necessario il ricorso al carcere". E conclui que se "riconoscere all'imputato una sorta di 'licenza' ad inquinare le prove".
} 
de provas, não sendo a prisão preventiva a única forma de se atingir tal fim. Em casos extremos, poderá haver até mesmo o cometimento de crimes contra a administração da justiça, tais como corrupção de testemunha ou perito (CP, art. 343), coação no curso do processo $(\mathrm{CP}$, art. 344), fraude processual (CP, art. 347, parágrafo único), sonegação de papel ou objeto de valor probatório ( $\mathrm{CP}$, art. 356), que poderiam ensejar, se for o caso, a prisão em flagrante e, quiçá, havendo proporcionalidade, além dos demais requisitos, a decretação da prisão preventiva por tais crimes.

Em suma, a proporcionalidade entre a prisão preventiva e a pena que provavelmente será aplicada ao delito não diz respeito apenas à prisão preventiva para assegurar a aplicação da lei penal, tendo incidência, também, no caso de prisão por conveniência da instrução criminal. ${ }^{55}$ Se não se projeta uma pena privativa de liberdade a ser cumprida no cárcere, diante da provável condenação, é ilegal a decretação da prisão preventiva, posto que incompatível com a natureza cautelar de tal medida. Deve haver uma proporcionalidade entre a pena que se prevê como provável em caso de condenação e a gravidade da medida cautelar a ser imposta ao acusado.

\section{O princípio da proporcionalidade e a natureza das medidas cautelares}

O princípio da proporcionalidade entre a medida cautelar e a provável pena a ser aplicada já é encontrado em vários ordenamentos jurídicos. ${ }^{56}$

Todavia, a ausência de uma regra expressa, o ordenamento jurídico brasileiro, impondo a proporcionalidade entre a medida cautelar e a pena que provavelmente será aplicada, não é impedimento para a posição que aqui se defende. A necessidade de que haja uma proporção entre a medida cautelar imposta - no caso, a prisão preventiva - e a pena projetada - no caso cumprimento de pena privativa de liberdade - é inerente ao sistema da tutela cautelar. ${ }^{57}$

Se a medida cautelar é acessória em relação a uma outra medida, no caso, o provimento satisfativo, parece óbvio que o assessório não pode superar ou ir além do principal. Isso é, a restrição imposta pela medida cautelar, para assegurar a utilidade do

\footnotetext{
${ }^{55}$ Deixamos de considerar as prisões para garantia da ordem pública e garantia da ordem econômica, por entendermos que tais medidas, por não ter natureza cautelar, mas de antecipação da tutela condenatória, são incompatíveis com o princípio da presunção de inocência.

${ }^{56}$ Sobre as previsões no direito comparado, cf. item 7.

${ }^{57}$ Merece destaque aresto do extinto TACrimSP: "Processo penal. Prisão cautelare Princípio da Proporcionalidade. Necessidade de exame da existência de certa correspondência entre a gravidade do crime e a necessidade de custódia cautelar. Concessão da ordem. Deve existir proporcionalidade entre a significação do crime e a manutenção da prisão cautelar do acusado, equilíbrio que o juiz não pode deixar de analisar, em obediência ao princípio da proporcionalidade penal, com assento no art. $5^{\circ}, \S 2^{\circ}$, Carta Constitucional, que assegura a proibição de excesso, aplicável também ao processo penal" (TACrimSP, HC n. 408.854-2, 10 Câmara, Rel. Des. Márcio Bártoli, j. 08.05.2002, v.u.).
} 
provimento a ser proferido no dito "processo principal", não pode ser mais gravosa do que o próprio resultado final do processo, em relação ao qual a medida cautelar é instrumental. Finalmente, sendo o provimento cautelar provisório, posto que tende a ser substituído por outro provimento, este sim, satisfativo e definitivo, não se pode aceitar que a restrição imposta por uma medida provisória e baseada em uma cognição sumária seja mais gravosa do que a medida imposta ao final.

Ao mais, o princípio da proporcionalidade é um princípio constitucional, ${ }^{58}$ que rege todo e qualquer ato estatal de restrição de direito fundamental do indivíduo. ${ }^{59}$ Assim, mesmo sem uma previsão expressa de tal princípio na normatização infraconstitucional da prisão preventiva, sua aplicação decorre da proteção constitucional do direito à liberdade e da própria natureza das medidas cautelares..$^{60}$

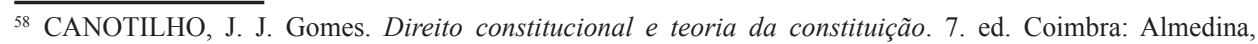
2003. p. 226 e seg.; Na doutrina nacional, manifestando-se pelo caráter constitucional do princípio da proporcionalidade: BARROS, Suzana de Toledo. O princípio da proporcionalidade e o controle de constitucionalidade das leis restritivas de direitos fundamentais. Brasília: Brasília Jurídica, 1996. p. 95; BARROSO, Luís Roberto. Interpretação e aplicação da Constituição. 6. ed. São Paulo: Saraiva, 2004. p. 218. Há posição que, sem divergir do conteúdo, nega que a proporcionalidade seja um princípio, considerando-o uma simples regra: (ALEXY, Robert. Teoria de los Derechos Fundamentales. Madrid: Centro de Estúdios Políticos y Constitucionales, 2002. p. 111) distingue as norma e princípios segundo sua estrutura e forma de aplicação. E, com base em tais premissas, nega que o chamado "princípio da proporcionalidade" seja um princípio verdadeiro, la maxima de proporcionalidad "no se trata de un principio en el sentido aquí expuesto. La adecuación, necesidad y proporcionalidad en sentid estricto no son ponderadas frente a algo diferente. No es que unas veces tengan precedencia y otras non". A resolução da questão passa pela definição prévia da dicotomia princípio/regra. Corretamente, (SILVA, Luís Virgilio Afonso da. O proporcional e o razoável. Revista dos Tribunais, São Paulo, n. 798, p. abr. 2002. p. 26) conclui que "mais importante do que a ingênua ambição de querer uniformizar a utilização do termo 'princípio' é deixar claro que ele, na expressão 'princípio da proporcionalidade', não tem o mesmo significado de 'princípio' na distinção entre regras e princípios, na acepção da teoria de Robert Alexy".

${ }_{59}$ BAROSIO, Vittorio. Il processo penale tedesco dopo la riforma del 1965. Milano: Giuffrè, 1967. p. 21, com base na doutrina alemã, afirma que "il principio di proporzionalità deve trovare applicazione 'per tutti i provvedimenti dello Stato nei confronti del cittadino, e perciò nell' ambito di tutto il diritto processuale penale"'. E, (FERNANDES, Antonio Scarance. op. cit., p. 55) afirma que o princípio da proporcionalidade constitui "um instrumento utilíssimo a serviço da efetividade dos direitos fundamentais e, especialmente, da liberdade". Analisando exatamente o art. $\$ 112$ da StPO o Tribunal Constitucional Federal da Alemanha decidiu que "Na República Federal Alemã, o princípio da proporcionalidade tem grau hierárquico de direito constitucional. Ele é derivado do princípio do Estado de Direito - na verdade da essência dos próprios direitos fundamentais, os quais, enquanto expressão da pretensão geral de liberdade do cidadão em relação ao Estado, só poderão ser restringidos pelo poder público quando a restrição foi imprescindível para a proteção de interesses público" (MARTINS, Leonardo (Org.) Cinqüenta anos de jurisprudência do Tribunal Constitucional Federal Alemão. Montevideo: Konrad-Adenauer-Stiftung, 2006. p. 312).

${ }^{60}$ Obviamente, como adverte (FERRAIOLI, Marzia. Le misure di cautela personale. In: Le nuove disposizione sul processo penale - Atti del Convegno - Perugia 14-15 aprile 1998. Milano: Giuffrè, 1989. p. 230) "quando s'introduce il criterio della porporzionalittà dovrebbero anche individuarsi i parametri ai quali deve rifarsi il giudice quando gradua la misura cautelari in base alla sanzione che ritiene possa essere irrogata". De todo aconselhável, portanto, que haja uma disciplina legislativa estabelecendo quais os critérios que o juiz deverá considerar para mensurar a pena que provavelmente será aplicada. Isso não significa, porém, que na falta de tais critérios, o principio da proporcionalidade não possa ser aplicado, ainda que o seja com uma maior dose de subjetivismo judicial. 
Finalmente, cabe considerar que não há óbice, do ponto de vista da atividade cognitiva do juiz, ${ }^{61}$ a que este faça um prognóstico da futura pena a ser aplicada, com base nos elementos que disponha no momento da análise de um pedido de decretação da prisão preventiva. Da mesma forma que, com base em uma cognição sumária, deverá analisar a presença do fumus commissi delicti e considerar, segundo o estado do processo e dos elementos de informação existentes, que há prova da existência de um crime e indícios suficientes de autoria, assim também deverá agir para considerar se é provável que, ao final, o acusado será condenado a uma pena privativa de liberdade, que não será suspensa ou substituída por pena de multa ou restritiva de direitos ou, ainda, cumprida em regime aberto.

A mesma cognição sumária que autoriza o reconhecimento do "direito hipotético" autoriza o reconhecimento da "pena hipotética", aferindo-se a proporcionalidade da medida.

Em suma, sendo provisória, assessória e instrumental, a restrição da medida cautelar não pode ser mais severa do que a pena definitiva, principal e que é o fim do processo penal. Para tanto, valendo-se de cognição sumária, o juiz deve verificar qual a provável pena a ser aplicada ao final do processo, somente decretando a prisão preventiva se esta for compatível com o prognóstico da sanção penal.

\section{O princípio da proporcionalidade e revogação da prisão preventiva}

O prognóstico da aplicação e cumprimento da pena privativa de liberdade deve ser considerado não-só no momento de decretação da prisão preventiva, mas também ao longo de toda a sua subsistência. Em outras palavras, o prognóstico da pena aplicada, enquanto elemento de aferição da proporcionalidade da prisão preventiva deve ser considerado como critério para decretação da medida ex ante e como fundamento para sua manutenção ou permanência ex post.

Sendo provisória, a prisão preventiva, como toda medida cautelar, "descansa sobre um juízo de probabilidade e é proferida segundo o estado da causa". ${ }^{6}$ Conseqüentemente, trata-se de medida revogável, desde que haja alteração do estado de fato ou de direito que justificou a sua decretação. ${ }^{63}$

\footnotetext{
${ }_{61}$ Para uma análise da cognição sumária no processo penal, cf.: BADARÓ, Gustavo Henrique Righi Ivahy. Ônus da prova no processo penal. São Paulo: Revista dos Tribunais, 2003. p. 417-422.

${ }^{62}$ MARQUES, José Frederico. op. cit., p. 53.

${ }^{63}$ CHIAVARIO, Mario. Appunti sul processo penale. Torino: Giappichelli, 2000. p. 402, vai além, não exigindo, nem mesmo que haja uma mudança do estado das coisas ou um fato superveniente, entendendo que a revogação da medida cautelar "può essere anche un ripensamento, sulla base del medesimo materiale già preso in considerazione, da parte dal giudice setesso che ha disposto la misura (o di un giudice successivamente investito del procedimento, in una fase ulteriore)" (destaque nosso).
} 
Na doutrina aponta-se como exemplo de situação que autoriza a revogação da prisão preventiva, ${ }^{64}$ o caso em que a prova colhida na instrução convence o juiz de que o réu será absolvido. Nesse caso, não deverá o juiz esperar a sentença absolutória, para revogar a prisão decretada para assegurar a aplicação da lei penal. ${ }^{65}$ Indaga-se: se o juiz pode e deve fazer um prognóstico sobre futura condenação ou absolvição, segundo o estado do processo, por que não deve fazer tal prognóstico, segundo a prova existente nos autos, ${ }^{66}$ tendo por objeto a provável pena a ser aplicada? Não há nada que difira uma situação da outra. Em ambas, com base em uma cognição sumária e provisória, o juiz analisa aspectos do direito material, para constatar se o fumus boni iuris ainda subsiste. No primeiro exemplo, cessou o fumus commissi delicti e a prisão deve ser revogada. No segundo caso, não há mais necessidade da prisão preventiva, visto que deixou de haver proporcionalidade entre a prisão cautelar e a pena que se antevê como provável ${ }^{67}$ Num e noutro, o desenrolar da instrução demonstrou que a aparência do direito com base na qual a medida foi deferida não correspondia à realidade.

Com base na mesma cognição sumária, segundo o estado do processo e das provas até então produzidas, a inovação da classificação do delito pode autorizar o reforço (CPP, art. 340, inc. III) ou a cassação da fiança. Se tal atividade serve para afastar a liberdade provisória, por que não se poderá exercer a mesma atividade para afastar a prisão preventiva?

Aliás, nesse campo, o art. 316 do CPP traz regra expressa sobre a possibilidade de revogação da prisão preventiva, quando o juiz, "no correr do processo, verificar a falta de motivo para que subsista". Entre os motivos necessários para a subsistência da prisão, inclui-se a proporcionalidade da medida cautelar em relação à provável pena privativa de

\footnotetext{
${ }^{64}$ Aliás, no regime originário do CPP, em que o art. 312 previa uma prisão preventiva obrigatória, admitia-se até mesmo que o juiz verificasse "não mais haver prova de que o criem, que o réu por acaso tenha praticado, se enquadra em alguma das figuras típicas que autorizam a prisão obrigatória” (MARQUES, José Frederico. op. cit., p. 54).

${ }_{65}$ TORNAGHI, Hélio. op. cit., p. 95.

${ }^{66}$ Com bem observar (ZAVASCKI, Teori Albino. Antecipação da tutela. cit., p. 35) a necessidade da revogação da medida pode não estar relacionada com a alteração do estado de fato, mas com a alteração do estado da prova.

${ }^{67} \mathrm{Na}$ StPO alemã, o $\S 120, \mathrm{n}$. 1, prevê que a prisão preventiva será revogada se deixar de haver proporcionalidade com a pena que se possa ser aplicada. Também no art. 299 do CPP italiano há previsão da revogação ou substituição da medida cautelar, quando não mais estejam presentes as condições para sua aplicação, entre as quais se inclui a proporcionalidade de medida cautelar com a pena. Por sua vez, o item 2 do referido artigo dispõe que: quando a medida cautelar não é mais proporcional à gravidade do fato ou à sanção que possa vir a ser aplicada, o juiz substitui a medida por outra menos grave. Como no CPP brasileiro não há uma gradação de medidas cautelares como ocorre no processo penal italiano, não será possível a substituição da prisão preventiva por outra medida cautelar menos grave. E, como a liberdade provisória não é alternativa à prisão preventiva, não restará ao juiz outro caminho a não ser reconhecer a ilegalidade superveniente da prisão, por ter se tornado desproporcional, revogando-a.
} 
liberdade a ser aplicada. Se prisão cautelar tornou-se desproporcional, não há mais motivo para que ela subsista, devendo ser revogada.

Em suma o princípio da proporcionalidade exige do juiz um prognóstico a respeito não-só de uma futura condenação, mas da pena a ser concretamente aplicada, bem como sujeita a manutenção da prisão preventiva a variações em função da progressiva produção da prova. ${ }^{68}$

\section{O princípio da proporcionalidade no Direito Comparado}

O princípio da proporcionalidade, estabelecendo uma relação de equilíbrio entre a medida cautelar a ser aplicada e a provável pena a ser imposta ao final do processo, já é encontrado, expressamente, em diversos ordenamentos jurídicos.

Na StPO alemã, o § 112, parte final, prevê que a prisão preventiva "não pode ser ordenada se pelo significado da causa e a pena ou medida de segurança e correção a se esperar resulte desproporcionada". ${ }^{99} \mathrm{O}$ dispositivo estabelece a proporcionalidade com requisito negativo da prisão preventiva. Em outras palavras, a prisão não será decretada se desproporcional à pena que se espera ser aplicada.

Os princípios da adequação e proporcionalidade também foram consagrados no CPP português de 1987, cujo art. 193, n. 1., dispõe: “As medidas de coacção e de garantia patrimonial a aplicar em concreto devem ser adequadas às exigências cautelares que o caso requerer e proporcionais á gravidade do crime e às sanções que previsivelmente venham a ser aplicadas". ${ }^{70}$ Neste dispositivo legal, diferentemente, a proporcionalidade é estabelecida em termos positivo, enquanto requisito necessário para a decretação da prisão: a da prisão cautelar somente será aplicada se proporcional à pena que, previsivelmente, será aplicada.

Também o CPP italiano, de 1988, prevê a proporcionalidade e a adequação como critérios de escolha das medidas cautelares. Especificamente com relação à proporcionalidade, o art. 275, n. 2, dispõe que "Ogni misura deve essere proporzionata all'entità del fatto e alla sanzione che sia stata o si ritiene possa essere irrogata" ${ }^{71} \mathrm{De}$

${ }^{68}$ Cf.: ZAPPALÀ, Enio. Le misure cautelari. Diritto processuale penale. 2. ed. Milano: Giuffrè, 1996. v. 1, p. 448; GIARDA, Angelo. Le misure cautelari. In: AMODIO, Ennio et al. Lezioni sul nuovo processo penale. Milano: Giuffrè, 1990. p. 157.

${ }^{69}$ O princípio da proporcionalidade foi acrescentado pela Reforma de 1965 da StPO.

${ }^{70}$ Por sua vez, também se afirma a excepcionalidade ou subsidiariedade da prisão preventiva: “art. 193, n. 2: “A prisão preventiva só pode ser aplicada quando se revelarem inadequadas ou insuficientes as outra medidas de coacção".

71 A expressão "sia stata o" foi introduzida pelo art. 14, letra b, da Lei n. 128, de 26.03.2001. Além disso, o art. 280, n. 2, prevê que: "La custodia cautelare in carcere può essere disposta solo per delitti, consumati o tentati, per i quali sia prevista la pena della reclusione non inferiore nel massimo a quattro anni”. 
forma semelhante ao diploma português, a legislação processual penal italiana também prevê a proporcionalidade como um requisito necessário para a decretação da prisão preventiva.

Mas, para que não se imagine que se trata de critério apenas compatível com a realidade do Velho Continente, o mesmo critério é encontrado em recentes diplomas de nossos vizinhos latino-americanos.

O Código de Processo Penal paraguaio, Lei n. 1.286/1998, em seu art. 236, estabelece que "La privación de libertad durante el procedimiento deberá ser proporcional a la pena que se espera".

$\mathrm{Na}$ Argentina, o Código Procesal Penal da Província de Buenos Aires (Lei n. 11.922, de 1998), no art. 146, letra "b", estabelece, entre as condições para que se determine a medida de coerção, a "proporcionalidad entre la medida y el objeto de tutela”.

Os dois códigos latino-americanos acima citados tratam da proporcionalidade como requisito para a decretação da prisão preventiva.

Por sua vez, a desproporção, como uma hipótese negativa para a decretação da prisão preventiva, à semelhança do modelo alemão, aparece no CPP chileno, de 2000, que traz uma regra de impossibilidade de decretação da prisão preventiva em caso de desproporcionalidade. O art. 141 estabelece que: "No se podrá ordenar la prisión preventiva cuando ésta aparezca desproporcionada en relación con la gravedad del delito, las circunstancias de su comisión y la sanción probable". ${ }^{72}$

No mesmo sentido é o art. 203 do Código de Processo Penal Tipo para América Latina, que estabelece a impossibilidade de ordenar a prisão preventiva nos crimes "que não tenham prevista pena privativa de liberdade ou quando, no caso concreto, não se espera uma pena privativa de liberdade que deva ser executada".

\section{O projeto de reforma do Código de Processo Penal}

O Projeto de Lei n. 4.208/2001 tem por objeto alterar o Código de Processo Penal, relativamente à prisão cautelar, liberdade provisória, com ou sem fiança, e institui novas modalidades de medidas cautelares.

\footnotetext{
${ }_{72}$ Dando concretude a tal regra, o referido artigo prevê: "No procederá la prisión preventiva: a) Cuando el delito imputado estuviere sancionado únicamente con penas pecuniarias o privativas de derechos, o con una pena privativa o restrictiva de la libertad de duración no superior a la de presidio o reclusión menores en su grado mínimo; b) Cuando se tratare de un delito de acción privada, y c) Cuando el tribunal considerare que, en caso de ser condenado, el imputado pudiere ser objeto de alguna de las medidas alternativas a la privación o restricción de libertad contempladas en la ley y éste acreditare tener vínculos permanentes con la comunidad, que den cuenta de su arraigo familiar o social".
} 
Especificamente no que interessa ao presente tema, prevê uma nova redação para o art. 282 do CPP, que estabelece como princípios gerais de todas as medidas cautelares, a necessidade e a adequação:
Art. 282. As medidas cautelares previstas neste Título serão aplicadas com base nos seguintes critérios:
I-necessidade para aplicação da lei penal, para a investigação ou a instrução criminal e, nos casos expressamente previstos, para evitar a prática de novas infrações penais;
II-adequação da medida à gravidade do crime, circunstâncias do fato e condições pessoais do indiciado ou acusado.

Posteriormente, no dia 3 de julho de 2007, o presidente da Câmara dos Deputados criou um Grupo de Trabalho para estudo dos projetos sobre legislação penal e processual penal que tramitam na Câmara dos Deputados, com vistas à sua inclusão na pauta. O Grupo de Trabalho apresentou uma emenda substitutiva global ao Projeto, pelo deputado João Campos, coordenador do Grupo de Trabalho. Não houve, porém, alteração relativa ao art. 282 .

O projeto trará um significativo avanço no sistema das medidas cautelares, tanto ao estabelecer os princípios da necessidade e adequação, quanto por criar várias modalidades de medidas cautelares alternativas à prisão, que somente será decretada quando outra medida cautelar não se mostrar adequada.

Não há, contudo, expressa previsão sobre o princípio da proporcionalidade, em especial no que diz respeito à medida cautelar a ser imposta e a pena provável a ser aplicada. Assim com se faz em relação à adequação e necessidade, será melhor que se deixe expressa, também, a exigência da proporcionalidade.

\section{A proposta de mudanças legislativas}

Bastaria que os exegetas e os tribunais interpretassem o Código de Processo Penal à luz da Constituição, ao invés de procurarem adaptar a Constituição à legislação ordinária, para que a proposta de modificação legislativa ora formulada fosse desnecessária.

Principalmente ao se atentar para a própria natureza das medidas cautelares, se percebe, claramente, que uma medida cautelar não pode impor uma restrição mais gravosa do que aquela que, ao final, poderá ser imposta na tutela definitiva cuja eficácia se pretende assegurar ou acautelar.

Infelizmente, contudo, a experiência tem mostrado que parece que os direitos fundamentais assegurados na Constituição somente são efetivados e ganham concretude quando passam a encontrar acolhida na legislação infra-constitucional. É como se a lei valesse mais que a Constituição. Mas se é assim, melhor o reforço na lei ordinária. 
Diante disso, propõe-se a expressa e explícita incorporação, ao Código de Processo Penal brasileiro, do princípio da proporcionalidade das medidas cautelares, assegurando que a decretação de uma prisão preventiva deve sempre levar em conta a pena que, provavelmente, será aplicada ao final do processo, em caso de condenação. Mais do que isso, é necessário, também, que a desproporção entre tal binômio, seja claramente considerada como uma causa de revogação da prisão preventiva.

Finalmente, levando-se em conta que já se encontra em tramitação um projeto de lei de alteração do Código de Processo Penal, no que toca às medidas cautelares, a proposta ora formulada levará em conta a nova sistemática do direito projetado.

Assim, na esteira do Projeto de Lei n. 4.208, de 2001, propõe-se a inclusão de um inc. III, na nova redação do art. 282, que passa a ser:
Art. 282. As medidas cautelares previstas neste Título serão aplicadas com base nos seguintes critérios:
I-necessidade para aplicação da lei penal, para a investigação ou a instrução criminal e, nos casos expressamente previstos, para evitar a prática de novas infrações penais.
II - adequação da medida à gravidade do crime, circunstâncias do fato e condições pessoais do indiciado ou acusado.
III - proporcionalidade com as sanções que previsivelmente venham a ser aplicadas.

Além disso, tendo em vista a revogação da prisão preventiva, propõe-se a seguinte alteração de redação para o art. 316 do Código de Processo Penal:
Art. 316. O juiz poderá revogar a prisão preventiva se, no correr do processo, verificar que ela tornou-se desnecessária, inadequada ou desproporcional, nos termos do art. 282, bem como de novo decretá-la, se sobrevierem razões que a justifiquem.

As mudanças propostas representam um reforço legislativo na busca de uma maior garantia para a tutela da liberdade.

\section{Conclusão}

A finalidade da prisão preventiva, enquanto medida de natureza cautelar e, portanto, compatível com a garantia constitucional da presunção de inocência, é assegurar a utilidade e a eficácia do provimento final a ser proferido na ação penal condenatória. Para tanto, a prisão preventiva poderá ser uma cautela instrumental, por assegurar a produção da prova, ou uma cautela final, por assegurar a futura aplicação da pena privativa de liberdade. 
Em nenhuma hipótese a tutela cautelar pode impor uma restrição mais severa que aquela a ser imposta pela tutela a ser proferida ao final, em relação a qual a medida cautelar tem finalidade meramente conservativa.

A prisão preventiva jamais poderá ser imposta quando, com base em cognição sumária se antever que a pena a ser imposta ao final, provavelmente, não será um pena privativa de liberdade, ou esta terá sua execução suspensa. Não cabe a prisão preventiva se, ao final do processo, o acusado não terá que cumprir uma pena privativa de liberdade.

Embora sem previsão expressa na legislação penal brasileira, há um "requisito implícito" para a decretação da prisão preventiva: proporcionalidade da medida cautelar com a sanção a ser imposta na sentença condenatória. A proporcionalidade é uma decorrência da própria natureza provisória, instrumental e assessória da tutela cautelar.

A possibilidade de aplicação do princípio da proporcionalidade, tendo por parâmetro a pena que provavelmente será aplicada, não afasta a necessidade de o legislador estabelecer critérios mínimos, com base nas penas cominadas, sem os quais não será possível a decretação da prisão preventiva. Atualmente, diante da possibilidade de aplicação da transação penal, da suspensão condicional do processo, substituição da pena privativa de liberdade de até quatro anos, por pena restritiva de direitos e mesmo do sursis, os critérios do art. 313 mostram-se desatualizados e necessitam ser adequados à nova realidade normativa.

A proporcionalidade também é critério para a manutenção da prisão preventiva. Se no transcorrer do processo as provas produzidas demonstram, ainda com base em uma cognição sumária, que a provável pena a ser aplicada não será privativa de liberdade, o juiz deverá revogar a prisão preventiva.

Depois de tantas modificações legislativas, o reconhecimento do princípio da proporcionalidade, como condição para a decretação da prisão preventiva, é fundamental para dar harmonia ao sistema.

Todavia, em termos de garantia da liberdade de locomoção, nunca será demais uma norma de reforço. Principalmente diante daqueles que insistem em negar concretude às normas constitucionais, esperando uma positivação de direitos nas leis ordinárias, será bastante útil a previsão expressa, no Código de Processo Penal, que a decretação da prisão preventiva deve obedecer ao princípio da proporcionalidade, com vista à provável pena a ser aplicada, o mesmo valendo para a revogação da prisão preventiva, quando a mesma se mostrar desproporcional à futura pena.

São Paulo, fevereiro de 2008. 


\section{Referências}

ALEXY, Robert. Teoría de los derechos fundamentales. Madrid: Centro de Estudios Políticos y Constitucionales, 2002.

AMODIO, Ennio et. al. Nouve reforme sulle misure caltelari e sul diritto di difesa. Milano: Giuffrè, 1996.

ARAÚJO, Sérgio Luiz Souza. Teoria geral do processo penal. Belo Horizonte: Mandamentos, 1999.

BADARÓ, Gustavo Henrique Righi Ivahy. Ônus da prova no processo penal. São Paulo: Revista dos Tribunais, 2003.

BAROSIO, Vittorio. Il processo penale tedesco dopo la riforma del 1965. Milano: Giuffrè, 1967.

BARROS, Romeu Pires de Campos. Processo penal cautelar. Rio de Janeiro: Forense, 1982.

BARROS, Suzana de Toledo. O princípio da proporcionalidade e o controle de constitucionalidade das leis restritivas de direitos fundamentais. 3. ed. Brasília: Brasília Jurídica, 1996.

BARROSO, Luís Roberto. Interpretação e aplicação da Constituição: fundamentos de uma dogmática constitucional transformadora. 6. ed. São Paulo: Saraiva, 2004.

BATISTA, Weber Martins. Liberdade provisória. Rio de Janeiro: Forense, 1981.

BEDAQUE, José Roberto dos Santos. Tutela cautelar e tutela antecipada: tutelas sumárias e de urgência (tentativa de sistematização). São Paulo: Malheiros, 1998.

BERTOLINO, Pedro Juan. Código procesal penal de la Província de Buenos Aires (Ley 11.922) comentado y concordado. 5. ed. Buenos Aires: Depalma, 1998.

CALAMANDREI, Piero Introduzione allo studio sistematico dei provvedimenti cautelari. Padova: Cedam, 1936, reproduzido. In: . Opere giuridiche. Napoli: Morano, 1983. v. IX.

CANOTILHO, J. J. Gomes. Direito constitucional e teoria da constituição. 7. ed. Coimbra: Almedina, 2003.

CARNELUTTI, Francesco. Diritto e processo. Napoli: Morano, 1958.

. Lecciones sobre el proceso penal. Tradução de Santiago Sentís Melendo. Buenos Aires: Ejea, 1950. v. II.

. Processo di esecuzione. Padova: CEDAM, 1931. v. II.

CHIAVARIO, Mario. Appunti sul processo penale. Torino: Giappichelli, 2000.

CHIOVENDA, Giuseppe. Instituições de direito processual civil. Tradução J. Guimarães Menegale. São Paulo: Saraiva, 1948. v. 1.

. Principii di diritto processuale civile. 3. ed. Napoli: Jovene, 1965. 
CORDERO, Franco. Procedura penale. Milano: Giuffrè, 2000.

DELMANTO JUNIOR, Roberto. As modalidades de prisão provisória e seu prazo de duração. Rio de Janeiro: Renovar, 1998.

DINAMARCO, Cândido Rangel. Instituições de direito processual civil. São Paulo: Malheiros, 2001. v. 1.

FERRAIOLI, Marzia. Le misure di cautela personale. In: Le nuove disposizione sul processo penale - Atti del Convegno - Perugia 14-15 aprile 1998. Milano: Giuffrè, 1989.

FERRAJOLI, Luigi. Diritto e ragione: teoria del garantismo penale. 5. ed. Bari: Laterza, 1998.

FREDERICO MARQUES, José. A prisão preventiva compulsória. In: Estudos de direito processual penal. Rio de Janeiro: Forense, 1960.

. Elementos de direito processual penal. Rio de Janeiro: Forense, 1965. v. IV.

GIARDA, Angelo. Le misure cautelari. In: AMODIO, Ennio et al. Lezioni sul nuovo processo penale. Milano: Giuffrè, 1990.

GOMES FILHO, Antonio Magalhães. Presunção de inocência e prisão cautelar. São Paulo: Saraiva, 1991.

GRECO FILHO, Vicente. Manual de processo penal. 6. ed. São Paulo: Saraiva, 1999.

GREVI, Vittorio. Libertà personale dell'imputato. In: ENCICLOPEDIA del Diritto. Milano: Giuffrè, 1974. v. 24.

. Misure cautelari. In: CONSO, Giovanni; GREVI, Vittorio (Orgs.). Profili del nuovo Codice di Procedura Penale. Padova: Cedam, 1996.

LACERDA, Galeno. Comentários ao código de processo civil. 7. ed. Rio de Janeiro: Forense, 1998. v. VIII. t. I.

. O processo cautelar. In: Estudos sobre o novo código de processo civil. Rio de Janeiro: Liber Juris, 1974.

LIEBMAN, Enrico Tullio. Unità del procedimento cautelare. Problemi del processo civile. Napoli: Morano, 1962.

LIMA, Marcellus Polastri. A tutela cautelar no processo penal. Rio de Janeiro: Lumen Juris, 2005.

LOPES JR., Aury. Introdução crítica ao processo penal: fundamentos da instrumentalidade garantista. 3. ed. Rio de Janeiro: Lumen Juris, 2005.

MARINONE, Luis Guilherme. Tutela cautelar e tutela antecipatória. São Paulo: Revista dos Tribunais, 1994.

MARTINS, Leonardo (Org.). Cinqüenta anos de jurisprudência do tribunal constitucional federal alemão. Montevideo: Konrad-Adenauer-Stiftung, 2006. 
MIRABETTE, Julio Fabbrini. Processo penal. 16. ed. São Paulo: Atlas, 2004.

NUCCI, Guilherme de Souza. Código de processo penal comentado. 5. ed. São Paulo: Revista dos Tribunais, 2006.

OLIVEIRA, Carlos Alberto Álvaro de. Efetividade e processo cautelar. Revista de Processo, n. 76, out./dez. 1994.

PISANI, Andrea Proto. Lezioni di diritto processuale civile. 2. ed. Napoli: Jovene, 1996.

RAMOS, João Gualberto Garcez. A tutela de urgência no processo penal brasileiro. Belo Horizonte: Del Rey, 1996.

SANCHES, Sydney. Poder cautelar geral do juiz no processo civil brasileiro. São Paulo: Revista dos Tribunais, 1978.

SANGUINÉ, Odone. Clamor público como fundamento da prisão preventiva. In: SHECAIRA, Sérgio Salomão (Org.). Estudos criminais em homenagem a Evandro Lins e Silva (criminalista do século). São Paulo: Método, 2001.

Prisão provisória e princípios constitucionais. In: Fascículos de ciências penais. Porto Alegre: Sérgio Fabris, 1992. v. 5, n. 2.

SCARANCE FERNANDES, Antonio. Processo penal constitucional. 4. ed. São Paulo: Revista dos Tribunais, 2005.

SIDNEI, Benetti. Prisão Provisória: direito alemão e brasileiro. Revista dos Tribunais, São Paulo, n. $669,1991$.

SILVA, Luís Virgilio Afonso da. O proporcional e o razoável. Revista dos Tribunais, São Paulo, n. 798, abr. 2002.

SILVA, Ovídio A. Batista da. As ações cautelares e o novo processo civil. 3. ed. Rio de Janeiro: Forense, 1980.

THEODORO JÚNIOR, Humberto. Curso de direito processual civil. Rio de Janeiro: Forense, 1996. v. II.

TORNAGHI, Hélio. Instituições de processo penal. 2. ed. São Paulo: Saraiva, 1978. v. 3.

TOURINHO FILHO, Fernando da Costa. Processo Penal. 22. ed. São Paulo: Saraiva, 2000. v. 3.

ZAPPALÀ, Enio. Le misure cautelari. Diritto processuale penale. 2. ed. Milano: Giuffrè. 1996. v. 1.

ZAVACKI, Teori Albino. Antecipação da tutela. 4. ed. São Paulo: Saraiva, 2005.

Antecipação de tutela e colisão de direitos fundamentais. In: TEIXEIRA, Sálvio de Figueiredo (Org.). Inovações do código de processo civil. São Paulo: Saraiva, 1996. 